DigitALCOMMONS @WAYNESTATE -
Michigan Journal of Counseling: Research, Theory and Practice

Volume 40 | Issue 2

Article 2

$12-1-2013$

\title{
Violence Prevention in Middle School: A Preliminary Study
}

Wendy K. Killam

Stephen F. Austin State University

Catherine B. Roland

Georgia Regents University

Bill Weber

Stephen F. Austin State University

Follow this and additional works at: https://digitalcommons.wayne.edu/mijoc

\section{Recommended Citation}

Killam, W. K., Roland, C. B., \& Weber, B. (2013). Violence Prevention in Middle School: A Preliminary Study, Michigan Journal of Counseling, 40(2), 4-11. doi:10.22237/mijoc/1385856060

This Article is brought to you for free and open access by the Open Access Journals at DigitalCommons@WayneState. It has been accepted for inclusion in Michigan Journal of Counseling: Research, Theory and Practice by an authorized editor of DigitalCommons@WayneState. 


\section{Violence Prevention in Middle School: A Preliminary Study}

\section{Wendy K. KIllam ${ }^{1}$, Catherine B. Roland ${ }^{2}$, and Bill Weber ${ }^{1}$ Stephen F. Austin State University ${ }^{1}$, Georgia Regents University ${ }^{2}$}

\section{Abstract}

Violence in schools continues reflecting violence within society. There is a growing need for violence prevention programs within the schools that provide students with the skills needed to cope with interpersonal and relationship issues effectively. This study was conducted at a middle school and there were 345 middle school students (6th to 8th grade) who participated in the study. The students participated in a violence prevention program. In this study, the researchers used a pre-test/post-test design and the results indicated that there were some changes in attitudes towards violence that occurred after the intervention.

\section{Violence Prevention in Middle School: A Preliminary Study}

With the growing acts of incivility and violence on today's K-12 school campuses, the need for prevention violence has never been more important. Major problems listed by schools in the United States are fighting violence and gangs (Algozzine \& McGee, 2011). School violence continues to be a major problem, with numerous contributing factors which need attention from many different angles. As an example, the lack of close relationships with parents has been linked with an increase in violence in boys such as physical fighting and violence with a weapon during early adolescent years (Stoddard, et. al., 2011). This is an indication that violence prevention efforts need to address family issues as well. Often children learn behaviors at home and then exhibit those

Wendy K. Killam is an associate professor at Stephen F. Austin State University. She coordinates both the Mental Health Counseling Program and the Student Affairs in Higher Education Program. She is active in the Association for Adult Development and Aging. Catherine B. Roland is a professor and Department Chair of Georgia Regents University's Department of Counselor Education, Leadership, and Research. Her research interests include adjustment issues in college students, transitions throughout the lifespan and bullying. Bill Weber is a professor at Stephen F. Austin State University. He is the coordinator of the Undergraduate Rehabilitation Services Program and Director of the Career Planning Laboratory. He has years of experience working as a rehabilitation counselor and has a strong research focus on career development and vocational assessment. 
behaviors in other places such as school, which typically can reflect the dynamics that play out in the home.

\section{Literature Review}

The impact of school violence is multifaceted. When violence occurs at school it can lead to victims feeling depressed and isolated. Researchers have indicated that some students who are victims of school violence skip school occasionally due to not feeling safe (Johnson, Burke, \& Gielen, 2011). Furthermore, Blosnich and Bossarte (2011) indicated that even low-level violence can result in negative emotional and psychological consequences for the victims. While the focus is often on violence against students, it is important to note that violence in schools occurs within social contexts and can also include violence against teachers, principals, counselors and other school-based personnel who have perceived or real experience with a level of violence in the school (Algozzine and McGee, 2011). In some school districts, teachers and other personnel have left the schools due to not feeling safe and believed violence within the community had impacted the atmosphere within the school (Algozzine \& McGee, 2011). Violent events in school are often reported in the news bringing attention to the issue (Espelage, et. al., 2013)

Often people think of extreme physical violence, shootings and rapes when it comes to school violence. However, there are numerous forms of school violence including bullying, intimidation and gang activity. Social and environmental factors can impact whether or not students participate in violent activities. Participation in violent activities increases significantly during adolescence (Stoddard et. al, 2011). For some students, peer pressure may be a factor in getting involved in violent activities. Kerbs and Jolley (2007) indicated that more than 50 percent of students may believe that the victims brought the violence upon themselves and that there is nothing wrong with teasing others who are different. Addressing these issues is a complex task yet too often the focus is merely on changing behaviors. Nadal and Griffin (2011) pointed out that hate crimes begin through language, harassment and incivility toward different youth, are examples of the microagressions we see in schools and family settings.

Many schools have focused on the changing behaviors and mandating punishment for behaviors using a no tolerance policy. They may combine this approach with conflict resolution skills but for some schools these efforts have not been enough (Johnson, Burke \& Gielen, 2012). School environment is an important factor in academic success and violence in schools is negatively impacting the development of students both academically and emotionally (Johnson, Burke \& Gielen, 2011). More than half of middle schools use some type of security or surveillance methods but these measures are costly and the research has not supported an increase in school safer or a reduction of fear of violence on the part of students (Gottfredson \& DiPietro, 2011). It is also interesting to note that violence may not always be reported. In fact, Algozzine and McGee (2011) found in their study that students were more likely to report school crime and violence than teachers or administrators. School climate has been closely linked to the perception of school violence. School climate can be impacted by having clear policies and procedures that are closely followed and developing positive relationships between all members of the school community 
(Bosworth, Ford, \& Hernandaz, 2011). When a school has a climate with an atmosphere that struggles with a climate of aggression, this impacts how students feel, and many may not feel safe (Leff, et. al, 2010).

\section{School Based Violence Prevention Programs}

Violence has become a major problem in schools and over 90 percent of school districts in the United States have implemented policies and procedures to attempt to prevent school violence (Johnson, Burke, \& Gielen, 2012). School based violence prevention programs have several advantages over other prevention programs. These programs teach students skills and reinforce skills to prevent violence. The focus on developing skills can help to increase social competencies (Sullivan \& Bradshaw, 2012). Also, it has been noted that bullying tends to increase during middle school years and is an area prevention programs can address through character building and teaching empathy (Gibbone \& Manson, 2010).

However, it is important to note that prevention and intervention programs have mixed results. The best programs tend to have support from administrators teachers, staff and students and are campus wide in nature (Blosnich \& Bossarte, 2011). Additionally, Gibbone and Manson (2010) also indicated that school wide programs that allow for peer mentoring and peer leadership can be effective when students are allowed to be involved in the development of the programs. Algozzine \& McGee (2011) suggested that while quite a bit is known regarding juvenile crime, there is a gap in the knowledge and literature in terms of the use of evidence based efforts that address violence within schools.

Chambers, Zyromski, Asner-Self and Muthoni (2010) researched perceptions of school counselors for being prepared if and when serious acts of violence occurred. Chambers et al., found that both counselors' years of experience, and community setting contributed to those perceptions. It appears that more research is needed on the attitudes related to violence, as well as creating patterns of behavior change in school settings. In this study, we attempt to begin to help fill that gap.

\section{Purpose of the Study}

Given the growing issue with violence in society, additional research is needed to determine if school based violence prevention programs can have an impact in reducing attitudes towards violence and violence occurring on schools campuses by students. Counselors need to consider what steps they can take to prevent and reduce violence among youth. The purpose of this study was to explore how the changes in attitudes of students about violence based on an eight week violence prevention program intervention. A pre-test/post-test design was selected in order to determine if significant changes in thought patterns and behavior patterns may occur as a result of the intervention. Other factors were not considered such as grades, fighting and family environment. These are factors that albeit important were not part of this brief study. This study focused on determining if the intervention may have made a difference and thus a pretest/ posttest design was selected. 


\section{Method and Sample}

Middle school students in grades 6 to 8 in East Texas attended a violence prevention program with parental consent. The program was conducted within the schools with the aim of decreasing school violence. In recent years, school violence has become a major concern and the school system wanted to take proactive steps to prevent issues. The study was approved by a community treatment center's institutional review board (IRB). Mental health providers from the treatment center went to the middle school for eight weeks for 50 minute sessions with groups of students to discuss violence and conducted the violence prevention program. The program was a collaborative effort between the middle school and the treatment center. As Farrell (2009) indicated the schools are a way in which a large number of individuals can be reached and continuity can be provided when it comes to violence prevention. This was a major reason why the program was implemented in the schools. In reviewing various curriculum, some curriculum focused only on a small number of high risk students while other curriculum focus on the entire student body (Farrell, 2009). In order to reach as many students as possible, the treatment center used the Second Step: A Violence Prevention Curriculum. This curriculum also has extensive research to support it. The curriculum has been designed to decrease aggressive behaviors and increase social skills. The curriculum focuses on teaching skills in the areas of empathy, problem solving and controlling emotions (Neace \& Munoz, 2012).

We focused on determining if changes occurred in attitudes. The questions were designed by the counselors after reviewing the curriculum to be specific for this intervention. A pre-test/post-test design was used to determine if changes in attitudes about various situations occurred. While there are numerous factors that could account for changes in attitudes, the questions were designed to address the information and situations presented in the curriculum. The hypothesis was that there would be a significant change in attitudes after the intervention. The participants were all enrolled in school and parental consent was obtained for participants to participate in this study. The interventions occurred during the regular school day with the counselors coming to the schools. With regards to the participants, the group was diverse and represented the diversity of the local population. There were 345 middle school students who participated in this violence prevention program. Of this number 57 percent were female and 43 percent were male. With regards to race and ethnicity, 43 percent identified as White, 31 percent as Black, 21 percent as Hispanic, three percent as bi-racial and two percent identified as other.

\section{Results}

Participants were asked to rate their feelings regarding specific situations that could be classified as violent or bullying behavior using a five point Likert scale. The questionnaire survey was competed before the violence prevention program started and again at the conclusion of the program. On several of the items there were changes in the percentage that were over five percent. This is significant in that it demonstrated that the interventions may have had some impact on attitudes and feelings of participants. The questions along with results of the survey are below in Table 1 with the percentage for each item. 


\section{Table 1}

\section{Percentage for Questions}

1. Teasing someone is a violent behavior.

I totally agree
I agree somewhat
I disagree somewhat
I totally disagree

2. Being in a fight is a lot of fun.

I totally agree
I agree somewhat
I disagree somewhat
I totally disagree

3. People don't get seriously hurt in a fight.

I totally agree

I agree somewhat

I disagree somewhat

4. It's okay for people to slap a

$$
\begin{aligned}
& \text { I totally agree } \\
& \text { I agree somewhat } \\
& \text { I disagree somewhat }
\end{aligned}
$$$$
\text { I totally disagree }
$$

5. Sometimes people deserve to be hit or hurt.

I totally agree
I agree somewhat
I disagree somewhat

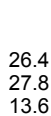

27.8 need to keep in line.

I totally disagree
6. It's okay for people to encourage their friend to fight if they have insulted.

$\begin{array}{ll}\text { I totally agree } & \\ \text { I agree somewhat } & 9.0 \\ \text { I disagree somewhat } & 20.9 \\ \text { I totally disagree } & 68.1\end{array}$

7. It's okay for children to be hit if they have done something wrong.

$\begin{array}{ll}\text { I totally agree } & \\ \text { I agree somewhat } & 9.0 \\ \text { I disagree somewhat } & 44.6 \\ \text { I totally disagree } & 42.9\end{array}$

I totally disagree
8. It's okay to walk away from a fight whether or not you think you had won.

I totally agree
I agree somewhat
I disagree somewhat
I totally disagree

9. If you want to protect yourself, you need to carry a gun.

$\begin{array}{ll}\text { I totally agree } & \\ \text { I agree somewhat } & 3.5 \\ \text { I disagree somewhat } & 14.5 \\ \text { I totally disagree } & 81.4\end{array}$

10. When parents are violent toward each other, they are usually the ones who are affected.

$\begin{array}{ll}\text { I totally agree } & \\ \text { I agree somewhat } & 19.7 \\ \text { I disagree somewhat } & 35.1\end{array}$

I disagree somewhat $\quad 35.1$

I totally disagree

11. People who are good fighters deserve a lot of respect.

I totally agree

I agree somewhat

I disagree somewhat

I totally disagree

12. Fighting is cool.

I totally agree

I agree somewhat

I disagree somewhat

I totally disagree
Pretest

$$
32.2
$$

$$
\%
$$

32.2

25.5

16.2

22.9

Pretest
1.2

$\%$

30.4

63.5

Pretest \%

12.2

25.5

55.4

Pretest \%

20.6

14.5

61.2

20.9 68.1

Pretest \%

14.5

Pretest \%

3.5

Pretest \%

56.2

Posttest \% 20.0

Posttest \% 3.8

Posttest \% 0.9

Posttest \% 35.4

Pretest \%

Posttest \% 3.5

11.0

19.1

66.4

Pretest \%

Posttest \% 0.6

Posttest \% 3.2

Posttest \% 48.7

Posttest \% 1.2

Posttest \% 15.7

Pretest \% 10.7

Pretest \%
Posttest \% 1.7

1.4 


\section{Discussion and Implications for the Counseling Profession}

There are several different violence prevention programs available. When selecting a curriculum it is important to consider the anticipated outcomes. Within this study, the students showed gains in terms of understanding violent behaviors as evidenced by shifts in the percentages on questions. However, there were some areas where certain percentages did not shift as much. This may be due to a number of environmental factors. Given that nearly 70 percent of the students in this school district are on free or reduced lunches, one must take into account the socio-economic status (SES) factors. Also, roughly half of the students were living with single parents or grandparents. One has to consider how this may impact the students' perceptions of violence especially if the parents often fight. These factors were not asked as part of the demographic background but could have impacted the results.

The results of this study can be used to consider areas in which violence prevention programs can provide students with additional information regarding what is considered violence. Also, programs may want to consider how they can provide students with additional hands-on experiences in handling difficult situations using role-playing and cases to facilitate personal growth in their ability to be prepared to deal with challenging situations.

\section{Limitations and Directions for Future Research}

There were limitations with this study. First only middle school students were included in the study. Also, participants were only those who attended a certain school in one state. It would be interesting to see if there are differences between students based upon region of the country. Also, it could be beneficial to see if older and younger students share similar attitudes. Although the sample was diverse in nature it may be beneficial to compare differences based on racial and ethnic groups. These aforementioned comparisons may potentially account for beliefs regarding violence. A study with a larger sample size could compare not only racial and ethnic differences but also gender differences. Additionally, in future studies, it would be important to take into account the SES background of the students if possible and to do some complex comparisons between various groups such as students from single parent families versus those from families with two parents. Another important area for research is the family dynamic and it how may have contributed to the level of behavior that would appear uncivil, mean, or violent that occurs in the school setting. There are also other factors that may have contributed to changes in attitudes that were not measured as well. Furthermore the study did not look at violence records in the schools or academic success. Future studies could take these factors into account. This additional information may assist counselors in providing a more tailored and structured approach to violence prevention, utilizing several avenues of response not researched in this study.

\section{Conclusion}

The rate of violence and incivility that seem to be occurring in schools is at an alarming rate. This should be addressed on multiple levels, and dedicated school violence prevention programs are one way to begin to address the issue 
of violence within schools and society. By providing children and young adolescents with the knowledge and skills they need to effectively cope with potentially violent and difficult situations, a reduction in school violence may occur. Continuing to work with families of bullied and bullying individuals is important in counteracting the negativity that can be seen in the home, and carried into the educational system, on all levels (Baldry, 2003; Mustanoja, Luukkonen, Hakko, Rasanen, Saavala, \& Riala, 2011). Additionally, the skills learned in violence prevention programs can be used throughout one's lifetime (Farrell, 2009). The attitudes and responses of children need to be considered when evaluating violence prevention programs. In this study, we have attempted to begin that process.

\section{References}

Algozzine, B., \& McGee, J. R. (2011) Reported occurrences and perceptions of violence in middle and high schools. The Clearing House: A Journal of Educational Strategies, Issues and Ideas, 84, 91-97.

Baldry, A. C. (2003). Bullying in schools and exposure to domestic violence. Child Abuse \& Neglect, 27, 713-733.

Blosnich, J., \& Bossarte, R. (2011). Low-Level violence in schools: Is there an association between school safety measures and peer victimization? Journal of School Health, 81, 107-113.

Bosworth, K., Ford, L., \& Hernandez, D. (2011). School climate factors contributing to student and faculty perceptions of safety and select Arizona schools. Journal of School Health, 1(4),194- 201.

Chambers, R. A.; Zyromski, B; Asner-Self, K.; \& Kimemia, M (2010). Preparedness for school violence: School counselors' perceptions of preparedness for responding to acts of school violence. Journal of School Counseling, 8, 35-41.

Espelage, D. Anderman, E. M., Brown, V. E., Jones, A., Lane, K. L., McMahon, S. D., Reddy, L. A., \& Reynolds, C. R. (2013). Understanding and preventing violence directed against teachers: Recommendations for a national research, practice and policy agenda. American Psychologist, $68,75-87$.

Farrell, A. D. (2009). The ecological effect of universal and selective violence prevention programs for middle school students: A randomized trial. Journal of Consulting and Clinical Psychology, 77, 526-542.

Gibbone, A., \& Manson, M. (2010). Bullying: Proactive physical educators' contribution to school-wide prevention. Journal of Physical Education, Recreation \& Dance, 81, 20-24.

Gottfredson, D. C., \& DiPietro, S. M. (2011). School size, social capital, and student victimization, Sociology of Education, 84, 69-89.

Johnson, S. L. Burke, J. G., \& Gielen, A. C. (2011). Prioritizing the school environment in school violence prevention efforts. Journal of School Health, $81,331-339$. 
Johnson, S. L., Burke, J. G., \& Gielen, A. C. (2012). Urban students' perceptions of the school environment's influence on school violence. Children and Schools, 34, 92-102.

Kerbs, J., \& Jolley, J. M. (2007). The joy of violence: What about violence is fun in middle-schools? American Journal of Criminal Justice, 32, 12-29.

Leff, S. S., Waasdorp, T. E., Paskewich. B., Gullan, R. L., Jawad, A. F., MacEvoy, J. P., Feinberg, B. E., \& Power, T. J. (2010). The preventions relational aggression in schools everyday program: A preliminary evaluation of acceptability and impact. School Psychology Review, 39, 569587.

Mustanoja, S.; Luukkonen, A.; Hakko, H.; Rasanen, P; Saavala,H., \& Riala, K. (2011). Is exposure to domestic violence and violent crime associated with bullying behavior among underage adolescent psychiatric patients? Journal of Child Psychiatry and Human Development, 42, 495-506.

Nadal, K., \& Griffin, K. (2011). Microagressioins: A root of bullying, violence, and victimization toward lesbian, gay, bisexual, and transgender youth. In M. Paludi (Ed)., The psychology of teen violence and victimization: From bullying to cyberstalking to assault and sexual violation. Santa Barbera, CA: Praeger.

Neace, W. P., \& Munoz, M.A., (2012). Pushing the Boundaries of Education: Evaluating the Impact of Second Step: A Violence Prevention Curriculum with Psychosocial and Non-Cognitive Measures. Child and Youth Services, 33, 46-69

Stoddard, S. A., Henly, S. J., Sieving, R. E., \& Bolland, J. (2011). Social connections, trajectories of hopelessness, and serious violence in impoverished urban youth. Journal of Youth and Adolescents, 40, 278-295.

Sullivan, T. N., \& Bradshaw, C. P. (2012). Introduction to the special issue of behavioral disorders: Serving the needs of youth with disabilities through school-based violence prevention efforts, Behavioral Differences, 37, 129-132. 